\title{
Crossing boundaries: an assessment to the influence of post-Keynesianism on developmental macroeconomics
}

\author{
Cruzando fronteiras: uma análise da influência do \\ pós-keynesianismo sobre a macroeconomia do desenvolvimento
}

VICTOR CRUZ E SILVA* MARCELO CURADO**

\begin{abstract}
RESUMO: A macroeconomia do desenvolvimento, a teoria econômica que baseia o novo desenvolvimentismo, é uma abordagem heterodoxa cujo estabelecimento foi profundamente influenciado por diversas escolas de pensamento. Entre estas, o pós-keynesianismo ocupa um lugar especial. Este ensaio pretende identificar os aspectos da macroeconomia do desenvolvimento nos quais a influência do pós-keynesianismo é mais notória. Para alcançar este propósito nós comparamos diagnósticos econômicos, objetivos sociais e prescrições de política defendidas pelos partidários destas duas escolas de pensamento econômico. Nossa conclusão é que apesar da significativa influência do pós-keynesianismo na formação da estratégia novo-desenvolvimentista, existem diversos aspectos desta estratégia que devem ser compreendidos como uma contribuição original da escola desenvolvimentista brasileira. PALAVRAS-CHAVE: Macroeconomia do desenvolvimento; novo desenvolvimentismo; póskeynesianismo; prescrições de políticas; influência teórica.
\end{abstract}

ABSTRACT: Developmental macroeconomics, the economic theory that grounds new developmentalism, is a heterodox approach whose establishment was deeply influenced by dissonant schools of thought. Among these, post-Keynesianism occupies a special place. This essay aims at identifying the aspects of developmental macroeconomics in which this postKeynesian influence is more notorious. To serve this purpose, we compare the economic diagnoses, social objectives and policy prescriptions defended by the partisans of these two schools of economic thought. Our conclusion is that despite the significant influence of post-Keynesianism in the formation of the new developmentalist strategy, there are several aspects of this strategy that must be understood as an original contribution of the Brazilian developmental school.

\footnotetext{
* Universidade Federal do Paraná, Curitiba/PR, Brasil. E-mail: victor.cruzesilva@gmail.co

* Universidade Federal do Paraná, Curitiba/PR, Brasil. E-mail: curado@ufpr.br. Submitted: 28/ March/2017; Approved: 8/March/2018.
} 
KEYWORDS: Developmental macroeconomics; new developmentalism; post-Keynesianism; policy prescriptions; theoretical influence.

JEL Classification: B22; B59.

\section{INTRODUCTION}

Developmental macroeconomics is one of the contemporary manifestations of the Latin American structuralism originally advanced by the ECLAC. This theory, until the publication of the book Developmental Macroeconomics, in 2014, was usually remarked as structuralist macroeconomics of development. It is also upon this theory that the national development strategy known as new developmentalism relies (Bresser-Pereira, 2011a, p. 493-494).

The raison d'etre of the structuralist bloodline is the perception that Latin America has a particular trajectory of development, submissive to the great international powers. The objective of the supporters of this idea is, therefore, the overcoming of Latin America's historically and structurally peripheral condition (Sunkel $\&$ Paz, 1976, p. 1-2). Bresser-Pereira (2011a, p. 493), then, defines developmental macroeconomics as "[...] a demand-side theory of development based on structural tendencies that constrain investment opportunities and limit the rate of growth of developing countries."

In the theoretical construction that led to this succinct definition, however, manifold theories were merged in the attempt to render developmental macroeconomics a coherent and strong heterodox approach to economics. As listed by Bresser-Pereira (2011b, p. 306), some of the individuals whose influence were decisive in the constitution of developmental macroeconomics are Adam Smith, Karl Marx, John Maynard Keynes, Michael Kalecki, Paul Rosenstein-Rodan, Gunnar Myrdal, Ragnar Nurkse, Arthur Lewis, Raul Prebisch, Celso Furtado, Hans Singer, and Albert Hirschman.

Developmental macroeconomics, therefore, counted with the influence of different - and sometimes conflicting - schools of thought. Accordingly, these schools conformed the way developmental macroeconomics adjusted the structuralist diagnoses and policy prescriptions to a more contemporary stage of social development, internal industrialization, and international integration.

One of the schools of thought whose influence was more notorious in this process is post-Keynesianism. This might be easily inferred from the several traditionally post-Keynesian Brazilian economists active in the production of scientific material in defense of the new developmentalist strategy, such as José Luis Oreiro, Luiz Fernando de Paula, and Nelson Marconi. The closeness of these individuals with both theoretical approaches may also, however, hinder the drawing of boundaries between them.

Therefore, the objective of this essay is to give more precision to the role played by post-Keynesianism in the establishment of developmental macroeconomics. 
More specifically, this essay aims at both the identification and systematization of the features of developmental macroeconomics whose origin is in the post-Keynesian paradigm. To enable this, we will compare how both traditions understand the functioning of the capitalist system as well as their policy prescriptions (fiscal, monetary, exchange rate, prices, and industrial). To serve this purpose, the main studies concerning these matters, both from post-Keynesian and developmental macroeconomics nature, shall be gathered and scrutinized.

Before delving into our analysis, however, three acknowledgments must be stressed.

First, it is not our purpose to label economists. It is very much possible that the same individual produces some works in the realm of post-Keynesianism and other works in the realm of developmental macroeconomics. The fact that a paper is used as reference for either theory, therefore, does not have any broader meaning. It simply means that the referenced paper reproduces that specific theoretical background. An example of this is José Luis Oreiro, whose intellectual production serves as basic reference for both one theory and the other.

Second, we do not ignore that Mollo and Amado (2015) categorize different kinds of new developmentalism. In fact, it is interesting to notice that a postKeynesian new developmentalism is defined. Unlike the authors, however, we consider that the new developmentalist strategy is necessarily tied to the developmental macroeconomics framework. Moreover, we believe that this characterization of a post-Keynesian kind of new developmentalism strengthens our defense of the influence post-Keynesian theory exercised upon developmental macroeconomics.

Third, we must also stress that sensitive differences exist in the method adopted by each of the analyzed theories. Developmental macroeconomics was built specifically to fit a group of peripheral countries, while post-Keynesianism was conceived on more universal premises. This dissonance might generate a too-bigto-be-neglected scope incommensurability. From the methodological standpoint, therefore, we found ourselves compelled to follow Landreth and Colander's (2001, p. 10) recommendation, restricting the width of our compass. Considering the distinction they apply to economic thought, our analysis will focus on the art of economics, to the detriment of positive and normative economics. This means that we ignore questions such as the purely ideal functioning of the economy from positive and normative angles and merge them into the question: "if these are one's normative goals, and if this is the way economy works, then how can one best achieve these goals?" (Landreth \& Colander, 2001, p. 11). Through the identification of the diagnoses, objectives, and policy prescriptions professed by post-Keynesianism and developmental macroeconomics, we believe that each piece of the puzzle proposed by Landreth and Colander will fall into place.

That said, this paper is organized in four sections beyond this introduction. Second section presents the post-Keynesian constructs concerning the way the economic system works and the policies prescript by the economists from this stream. Third section will perform the same task advanced in the previous section, but focusing on the developmental macroeconomics approach. Fourth section, the article's 
core, will try to cross the boundaries between the two schools. Finally, the fifth section will sum up the main arguments of this work in some brief concluding remarks.

\section{DIAGNOSIS AND POLICY PRESCRIPTIONS I: THE POST-KEYNESIAN THEORY}

Oreiro's (2011, p. 290) definition of the post-Keynesian research agenda is the one we adopt throughout this paper. He characterizes the theory's encompassing leitmotif as the comprehension of the way Keynes systemically and analytically saw the functioning of the economy, based on the empirical verification that the laissezfaire system does not work. Since the GT was published in a high-variation inflation, unemployment, and national budgets period, it was a reaction to great (self-amplifying) economic imbalances. This self-amplification, in its turn, was fostered by a sentiment of fundamental uncertainty about the future. Dialectically, on the other hand, the intensity and the extent to which uncertainty acts upon the economy tended to be accentuated by this same self-amplification (JESPERSEN, 2009, p. 1).

This recognition posed a serious theoretical challenge to the neoclassical constructs. The determinacy of the future and the perennial tendency to stationary full-employment equilibrium were, although still dominant, no longer consensual. ${ }^{1}$ Davidson (2002, p. 11) points out that two main characteristics of the economic system noted by Keynes are the cornerstones of the post-Keynesian challenge/ analysis: ${ }^{2}$ a) crucial economic decisions cannot have their future outcomes measured a priori; and b) production and commercialization are not simultaneous cash flow processes. Hence, the entrepreneurs are bound to the necessity of making “ [...] money contractual commitments in the present involving performance and payments at specified dates in the uncertain future."

The merger of these two fundamental characteristics results in the peremptory denial of the money neutrality axiom. Money, so, plays a paramount role in the dynamics of the economy, and this verification alters the entire idea of how the system functions, both theoretically and in reality. The neoclassical dichotomy no longer holds. Robert Skidelsky (1992, p. 442), the most prominent of Keynes' biographers, alleges that, for Keynes, the monetary side of the economy acted upon economic performance not only through temporary disturbances. For him, monetary forces " $[\ldots]$ entered fundamentally into the determination of equilibrium states.

\footnotetext{
${ }^{1}$ The German Historical School and Institutionalist economics are two heterodox approaches that also presented, in the late-1800s and early-1900s, severe critiques to this idea of economic system.

${ }^{2}$ By post-Keynesian analysis we intend to deal with the branch of post-Keynesianism that is defined as fundamentalist and embraces, among others, Joan Robinson, Hyman Minsky, Victoria Chick, Paul Davidson and Fernando Cardim de Carvalho. We disregard, therefore, the Kaleckian and the Sraffian ones. In fact, we believe that classifying Kalecki and Sraffa as post-Keynesians is not fair with the roles these individuals played in the history of economic thought. For further information about these branches - and the controversy surrounding their classification as post-Keynesians -, see Lavoie (2009, p. 19-20).
} 
All economic values were monetary values, which meant that the theory of money and the theory of production could not be separated."

Furthermore, according to Davidson (2002, p. 13), "It was Keynes's liquidity preference theory of money and financial markets that was the revolutionary aspect of Keynes's analysis." In other words, the diagnosis is that the real and monetary sides of the economy are necessarily interdependent, both in the short and in the long runs. The term coined to represent this scheme is monetary economy of production.

This monetary economy of production can, according to Minsky (1986, p. 11), be described as intrinsically cyclical because of its unstable nature. The processes and events that generate the cyclical behavior of capitalism cannot, though, as presupposed by the adepts of what Joan Robinson named 'bastard Keynesianism', be attributed to exogenous shocks. ${ }^{3}$ The continuous fluctuation, an contraire, is endogenously nurtured due to the contradiction between individual and social rationalities. Therefore, as posed by Carvalho (1999, p. 266), uncertainty may not be eliminated, so there is no mechanism, policy, or institution that can prevent the fluctuation from happening. Consequently, crises will, from time to time, inevitably surface. This acknowledgment answers for the necessity of a countercyclical force that legitimates state intervention in the economy. In the macro sense, ${ }^{4}$ the market ought to be sheltered under the dome of big government and Central Bank as lender-of-last-resort, in Minsky's $\left(1986\right.$, p. 17) terms. ${ }^{5}$ These institutions, recognizing their inability to eliminate the cycles, should act, then, toward the mitigation of uncertainty, and, through that, attempt to reduce the severity of the cycles and shorten the distance between its peaks and valleys.

Based on this uncertainty/instability notion, an adjacent acknowledgment provides the most solid rationale for the active role of the state: markets cannot sustain full employment by themselves. In Keynes' words (1936 [1964], p. 372), “The outstanding faults of the economic society in which we live are its failure to provide for full employment and its arbitrary and inequitable distribution of wealth and incomes." Manifold instruments could be used to solve the income concentration issue. Keynes, however, like Schumpeter, believed that different levels of commitment and risk-taking should grant different amounts of economic reward. Therefore, Keynes judged that full employment was a more urgent question. This guideline

\footnotetext{
${ }^{3}$ These shocks can, however, deepen and/or accelerate the descent of the economy; the same is true regarding the upward movement, which can also be exacerbated by exogenous and random events.

${ }^{4}$ Carvalho (1999, p. 270) is very clear in his defense of intervention exclusively in the macro sense. Microeconomically, agents are still obliged to face instability/uncertainty contexts, binding their economic fates to their choices and successes. The government should intervene to reduce global or macroeconomic risks, not to transfer its original impact points.

${ }^{5}$ Minsky (1986, p. 222) recognizes that this expedient might engender moral hazard, a point largely explored by the orthodox economists in their criticism of his thought. Arestis and Sawyer (1998, p. 191), nonetheless, insightfully, although not explicitly, provide an idea of how imperative are the two great institutions idealized by Minsky. According to them, "competition will always involve winners and losers, and major losers will be the workers in the firm which does not survive."
} 
served as a compass to post-Keynesians and their policy prescriptions. Accordingly, the government should subsidize and support market operation, making it possible to achieve full employment - even though the government's presence does not assure its realization (Carvalho, 1999, p. 267). A state-guided economy would be a necessary condition for full employment, but it could not be taken as a sufficient condition per se.

In sum, the aim of post-Keynesian policy prescriptions is the maintenance of an adequate level of aggregate demand. To serve this purpose, post-Keynesianism offers a consistent and coordinated policy framework, embodying fiscal, monetary, exchange rate, price and industrial policies.

The economic policy recommendations here described are largely based on Arestis and Sawyer (1998) and Carvalho (1999). The rationale behind this is the considerable centrality of both studies, represented by the number of citations they received. According to the Google Scholar database, Arestis and Sawyer's paper received 141 citations. This means that it is the ninth most quoted paper written by Sawyer and the eleventh most quoted Arestis' paper. Nevertheless, it is the most cited paper concerning generic policy prescriptions for both authors. Carvalho's book chapter, on the other hand, received 83 quotes, and comes in third among the references to Carvalho in the same database. ${ }^{6}$ Even though Arestis and Sawyer's paper received more quotes, we believe Carvalho's number to be even more impressive than theirs, because the language barriers imposed by a study published in Portuguese are significant and must be considered.

Germane to fiscal policy, flagship of any Keynesian tradition, the proposal is the same outlined by Keynes in the GT. An active fiscal policy requires the set-up of two distinct budgets: one concerning the ordinary functions of the public administration and the other concerning the discretionary outlay. The basic premise underlying these budgets is the need for equivalence between government revenues and expenditures. The ordinary budget must be integrally balanced. The discretionary one, on the other hand, is the tool the big government has to sustain aggregate demand - and thus the level of employment - in periods of aggravated market pessimism. The success of this fiscal effort should not be measured by the amount of currency employed in it, but by its capacity of signalization that the state is able and willing to intervene whenever necessary.

The monetary policy, to which Keynes devoted a considerable part of his academic work, in its turn, is essentially an instrument of both control and information. It must ensure the stability of the financial system ${ }^{7}$ and indicate to the agents that the actual interest rate is - and will remain - lower than the normal interest rate. The normal interest rate is the one flagged by the market, but each individual perceives it rather differently. This is the central feature of post-Keynesian monetary

\footnotetext{
${ }^{6}$ These were the consolidated positions on February 22, 2017.

${ }^{7}$ Post-Keynesian financial system is better portrayed as a finance-investment-saving-funding circuit. For a deeper understanding regarding this system, see Arestis and Resende (2015) and Studart (1995).
} 
policy. Accordingly, as defended by Carvalho (1999, p. 275, free translation), “opinion divergences regarding what is considered normal in the interest rate are an essential element of Keynes' liquidity preference theory."

The fact that the conservation of a lower interest rate will have a direct impact on prices did not go unnoticed. Notwithstanding, it is considered that the pros arising from this indispensable feature more than compensate the cons. Whenever necessary, e.g., in moments of excessive inflationary pressure, the reduction of aggregate demand could be made by other means.

The next basic policy, the one regarding the exchange rate, is not very explored by the usual post-Keynesian literature. Arestis and Sawyer $(1998)^{8}$ look upon exchange rate policy as very closely attached to the operation of the monetary dynamics. Once again, the target is macroeconomic stability and, to make it possible, an international monetary system without a deflationary bias is imperative.

Therefore, a stable level of exchange rate that encourages trade comes to evidence. However, the fixed exchange rate regime had undergone bankruptcy with the end of Bretton Woods and the flexible regime brings too much volatility to the exchange rate. It is proposed, then, a middle ground: an adjustable peg system, which allows "deficit countries to overcome the deficit position" (Arestis \& Sawyer, 1998, p. 189).

In reference to price policy, also embedded in the monetary system, there must be mechanisms to counterbalance two potential destabilizing problems. First, there is the possibility of an inflation of raw materials; second, the distortion of wages could ignite the variability of prices.

Raw materials inflation is a problem with a relatively simpler solution (from the theoretical standpoint, at least). To fight it, an international stabilization fund would have to be created, defining intervals in which the prices could fluctuate. The question regarding salaries, in contrast, is a more sensitive issue. Intervention in this area requires some elements - and generates several consequences - that transcend the economic sphere and comprehend political and psychological aspects.

The labor unions, responsible for the negotiation of wages, are shortsighted in the sense that they negotiate the salaries of a small group of workers in an atomistic manner. ${ }^{9}$ This shortsightedness could push the level of wages to one that is incompatible with a reasonable inflation. For this reason, some authors of postKeynesian shade sustain a partial coordination and centralization of these negotiations at the macroeconomic level.

Last but not least, we have industrial policy. To the post-Keynesian school, this is not a major form of intervention as well, but it cannot be cast aside. Industrial policy, lato sensu, is evidently the one engaged in developing an economy's industry.

\footnotetext{
${ }^{8}$ Carvalho (1999) does not treat this matter explicitly, corroborating the argument that, even though considered, exchange rate is not a major post-Keynesian concern.

${ }^{9}$ Given that for post-Keynesians not only individuals but also institutions have bounded rationality, it could not be different.
} 
On that account, it should not exist just to correct market failures, since it is through this mechanism that the state commits itself to a developmental role in economic policy. Industrial policy, thus, from a post-Keynesian perspective, must provide a clear conjuncture in which both public and private agents are able to proceed with their activities.

These five policy expedients represent the way post-Keynesianism normatively establishes the complementarity between state and market. It is important to highlight that, in opposition to the mainstream belief, state and market are, as put by post-Keynesians, not competing, but complementary institutions. The greater the harmony in their coexistence, the better the economic structure should operate.

\section{DIAGNOSIS AND POLICY PRESCRIPTIONS II:}

\section{THE DEVELOPMENTAL MACROECONOMICS THEORY}

There are three different theoretical marks in the short history of developmental macroeconomics. The first is the appearance of the term new developmentalism, in 2003, by the hands of Luiz Carlos Bresser-Pereira, in the book Development and Crisis in Brazil (BRESSER-PEREIRA, 2011a, p. 496). This was important to outline the modus operandi of the development strategy that underlies this doctrine. The second is Bresser-Pereira's summarization of the new ideas underpinning new developmentalist proposals in the French edition of the book Globalization and Competition (Mondialisation et Compétition), in 2009. Robert Boyer, in his preface to the French edition of the book, was the first to realize that the book gave birth to a new economic theory that would become known as Structuralist development macroeconomics (BRESSER-PEREIRA, 2011b, p. 306). This marked the foundation as well as triggered the organization of an independent economic theory. The third is Bresser-Pereira, Oreiro, and Marconi's renaming of this theory, in the book Developmental Macroeconomics, published in 2014. This book was originally entitled Structuralist Development Macroeconomics. However, in order to avoid any confusion between the theory proposed and the Anglo-Saxon structuralism, ${ }^{10}$ the modification of the epithet was suggested by the publishing house (Routledge) responsible for its release. Structuralism as conceived by Latin-Americans is relatively undiffused in the North hemisphere (Bresser-Pereira, 2014).

As mentioned in the first sction, developmental macroeconomics is a contemporary adaptation of the Latin-American/ECLAC structuralism (henceforth structuralism), inaugurated in 1948. Furthermore, it served as the cornerstone of the developmentalist strategy, prevalent in Latin America until the 1980s.

\footnotetext{
${ }^{10}$ According to Missio, Jayme Jr. and Oreiro (2015, p. 258), it is consensual that structuralist macroeconomics, to which we added the adjective Anglo-Saxon, was conceived and formalized by Lance Taylor. "In this approach, one highlights the importance of institutions and the functional distribution of income among productive sectors and social groups."
} 
The most prominent economists of the original structuralist tradition are the Argentinian Raúl Prebisch and the Brazilian Celso Furtado. Grounded on the historical-structural method, this school of thought had as its most basic premise the recognition of the orthodoxy's incapacity to explain how the idiosyncratic LatinAmerican structure worked. Moreover, the understanding of Latin America's development would only be possible through a markedly historical and institutional analysis. Therefore, the mainstream imposition of the Ricardian law of comparative advantages would have done nothing but contribute to the deterioration of the region's economic situation. Through this, the central countries dictated an bacia fuera (outwards) pattern of primary goods export to non-industrialized countries, in which the dynamic component of the economy was external demand (Carneiro, 2012, p. 752; Mollo \& Amado, 2015, p. 3).

The pioneer diagnosis developed by Prebisch (1949 [1986]) rested upon the conception of the center-periphery scheme. According to Prebisch (1949 [1986], p. 479-480), the world is divided between a small number of industrialized countries, that form the center, and a majority of heterogeneous and non-industrialized nations, which constitute the periphery. In his conception, the benefits of the international division of labor would not spread uniformly among different countries. $A u$ contraire, the diffusion of improvements arising from it, while fast and homogeneous in central nations, is slow and wealth concentrating in the peripheral ones. This is caused by the absence of a dynamic industrial sector, responsible for the generation and diffusion of technical progress (Prebisch, 1949 [1986], p. 482). When added to the deterioration of the balance of payments, this would consistently undermine the peripheral 'life standard of the masses' (niveles de vida de las masas) (Prebisch, 1949 [1986], p. 479). From this, Prebisch arrived at the clear-cut conclusion that underdeveloped countries have the need to industrialize. Nothing else would be capable of transmitting the productivity enhancement to every stratum of the society.

This geographical and historical qualification of Latin America's structure and the necessity of a theory considering these specificities commanded an undeniable influence in the 1950s and in subsequent decades. The structuralist defense of the state's active management of industrialization came into vogue. Thereby, the policies prescribed in order to achieve this goal became the bedrock of Latin-American governments' development strategy.

However, the effectiveness of the developmentalist strategy was eventually exhausted, regardless of the positive impacts it had on the post-war economic performance. In addition, the reality of international capitalism, as the theory's own internal consistency would indicate, suffered dramatic changes since structuralism was first conceived. In light of these historical developments, structuralist thinkers had to endeavor in constant adaptations of their theory. Even though we could infer, a priori, that this represented a loss of ideological coherence, it illustrated, au contraire, an absolute commitment to their omnipresent historical-structural method (Bielschowsky, 2000, p. 16-17).

In line with this acknowledgment, is Bresser-Pereira's (2006, 2007, 2011a) 
introduction, in the early 2000s, of a new stage in the essentially Latin-American theories. There are two vital contextual differences in relation to the original 1950s' Eclac environment. First, new historical events changed the international scenario and made capitalism transit from the golden age of economic growth to the age of globalization. Second, medium developed countries, such as Brazil and other LatinAmerican ones, improved their own development stage and overcame the infant industry. This new phase of historical-structural method application, yet to be detached as a de facto theory, would be called developmental macroeconomics. The aim of the new theory was to offer 'an eclectic and pragmatic' (Mollo \& Fonseca, 2013 , p. 228) middle ground between pioneer structuralism and conventional orthodoxy.

Developmental macroeconomics adopts fully both classical developmentalism's concept of economic development as structural change and Prebisch's critique of the law of comparative advantage. Hence, it criticizes the homogeneous application of the Ricardian law of comparative advantages. Accordingly, “[...] structuralist development macroeconomics [yet to be named developmental macroeconomics] sees a chronically overvalued currency as the impediment to growth" (BresserPereira, 2011a, p.494).

A central claim of developmental macroeconomics is that there is in developing countries a tendency towards the cyclical and chronic over appreciation of the exchange rate (Bresser-Pereira, 2010). This plays a central role in the theory. There are two causes for this long-term appreciation: the usual adoption of a high interest rate to attract capitals and a non-neutralized Dutch disease. The consequence that arises from this is that the exchange rate, which is usually conceived as a shortterm variable, becomes a long-term one and "enters" the investment function. For the several years that the exchange rate tends to remain overvalued during the financial cycle resulting from this tendency, the companies are discouraged to invest - not because there is no demand, but because there is no access to domestic or foreign demand (Bresser-Pereira, 2014). Accordingly, in this theory, the Dutch disease represents a long-term overvaluation of the exchange rate in peripheral countries. This generates a situation in which the exchange rate responsible for making the exports of commodities profitable in these countries is substantially more appreciated than the exchange rate required by the most technological manufacturing industries to be competitive.

As to the interest rate, new developmentalism is critical of growth with foreign indebtedness policy, because, due to the appreciation of the national currency caused by the necessary capital inflows, foreign savings do not augment the stock of total savings, but simply replace the domestic ones. Thus, if such policy is rejected and the Dutch disease is neutralized, the whole tendency to the cyclical and chronic overvaluation of the exchange rate should be neutralized.

The main concern of developmental macroeconomics' policy prescriptions is maintaining low the level of the basic interest rate around which the central bank makes its monetary policy and keeping neutralized the Dutch disease, and, consequently, achieving a reasonable level of macroeconomic stability, only achievable 
through the correct management of five macroeconomic prices. These five prices are: the inflation rate, the interest rate, the profit rate, the real wage rate, and, above all, the exchange rate (Bresser-Pereira, 2005, p. 3). The mechanisms whereby these prices might be controlled and macroeconomic stability might be achieved are very specific. ${ }^{11}$

The recommended fiscal policy is based on the equilibrium of the fiscal budget ${ }^{12}$ and on the accounting of the investment outlays in a separate category of spending, called capital account. The Treasury, then, should define a surplus target for the current budget, which would include the interest payments on public debt. After that, the Treasury would have to decide the amount of investment to be made respecting that restriction.

The monetary policy, in its turn, would have to be based on the enlargement of the Central Bank's functions. More specifically, the maintenance of an equitable balance of payments by means of the exchange rate policy would be added to the Central Bank's affairs. In practice, this instrument would be used pari passu with the interest rate to pursue the stability of two fundamental economic features, i.e., inflation and the balance of payments. At the mercy of the Central Bank, then, we just numbered three of the five fundamental macroeconomic prices conceptualized by Bresser-Pereira (2005, p. 3).

Additionally, the monetary policy should send signs to the private agents to induce them to trace the path the policy makers want them to. It could be signaled, for instance, that the interest rate is low enough to grant the profitability of private enterprises, stimulating new investments in production.

The exchange rate policy, now added to the Central Bank's responsibilities, rises as the most important state intervention mechanism. Given that the exchange rate is the strategic macroeconomic price, it must be administered for the benefit of the balance of payments and of the international reserves. Economic activity must be export-oriented (Mollo \& Amado, 2015, p. 9). This argument is paved on the experience of countries that had an accelerated growth in the post-war period, such as South Korea. Its aim is to generate surpluses in the current account. Therefore, it would be the mechanism capable of securing the sustainability of the balance of payments and of discouraging the realization of external loans. Oreiro

\footnotetext{
${ }^{11}$ New developmentalist policy prescriptions shall be portrayed blending the ideas presented by Bresser-Pereira (2006, 2007, 2011a), Oreiro and Paula (2012) and Sicsú, Paula and Michel (2007). Unlike the post-Keynesian case, developmental macroeconomics offers a restricted number of papers whose central goal is the normative establishment of policy recommendations. Therefore, the definition of an objective criteria is jeopardized. The papers used in this section as main references to developmental macroeconomics' policy prescriptions are the ones we found more compelling.

12 One of the practical flaws the mainstream usually appoints in the 'old' developmentalism is that it tended to generate severe budget deficits. At least partially, new developmentalists incorporate this criticism. However, as shown by Carneiro (2012, p. 772) and Mollo and Fonseca (2013, p. 228), attributing this stigma to structuralists is not entirely fair. For a detailed presentation, the reader may look for the aforementioned papers.
} 
and Paula (2012, p. 13-14), for example, recognizing the centrality of the exchange rate, issue a concrete policy recommendation. According to them, the creation of an Exchange Rate Stabilization Fund would be necessary. This Fund, in its turn, would count with an initial contribution of $\mathrm{R} \$ 300$ billion, with resources supplied by the Treasury Department in the form of government bonds. This engine would allow the monetary authority to act as a market maker. Because the origin of its resources is the National Treasury, it would not derail the reconciliation of monetary and exchange rate policies.

Analogously to exchange rate policy, price policy, by definition, cannot be separated from the monetary agenda. This verification arises from the acknowledgment that the route towards the management and control of inflation is necessarily - but by no means exclusively - correlated to the use of the interest rate apparatus. For every author outlined as a reference for the study of new developmentalist policy prescriptions, there's a theoretical background that demands the interest rate at the lowest feasible level compatible with the stability of prices.

Once again, there is a concrete policy recommendation in Oreiro and Paula (2012, p. 13-14). As stated by these authors, the institutional arrangement permeating the inflation-targeting regime ought to be ameliorated in three aspects. First, the effects of distortions in food and electric energy prices - that are more sensible to supply shocks - should be crossed off the basic index. Second, the term of convergence towards the target would be better extended to 24 months, avoiding the necessity of sudden and rough interest rate adjustments. Third, in extreme circumstances, the monetary authority should be authorized to use 'escape clauses' that would result in the divergence between the actual inflation rate and the targeted one.

Finally, there is industrial policy. Developmental macroeconomics does not dispense much attention to this subject. Since it is presupposed that the infant industry period has been overcome, the prosperity of the region relies heavily on its companies' ability to diversify and compete internationally. More specifically, every sector of the economy, especially the ones responsible for a high aggregate value, should be export-oriented.

For this reason, Bresser-Pereira (2012, p. 362) regards new developmentalism as non-protectionist. Its objective is to balance the scales on behalf of the manufacturing industries of the developing countries - something the market does not guarantee. Therefore, the competitiveness of firms has to flourish in order to nurture growth. It must be considered, nevertheless, that the administration of the exchange rate plays a significant role in the protection of national industry. In this sense, the categorization of new developmentalism as non-protectionist has to be relativized, given that, to a certain degree, there is a blockage to foreign companies' entrance in the domestic market and an incentive for the export of national enterprises. 


\section{DIAGNOSIS AND POLICY PRESCRIPTIONS III: CROSSING BOUNDARIES}

In order to begin the comparison between the two previously presented approaches and the measurement of the post-Keynesian influence on developmental macroeconomics, the first step is to make clear that developmental macroeconomics is not simply a geographical variation of post-Keynesianism. The influence of the latter over the former's objectives and policy prescriptions is - as verified - unquestionable, though. This relation is made explicit by Bresser-Pereira (2011b, p. 305), who defends that a Keynesian-structuralist school, responsible for the new developmentalist strategy, is blossoming in Brazil. Table 1, located at the end of this section, furnishes a summary of this comparison and shows the main points in which developmental macroeconomics either converge or diverge from postKeynesianism.

Even though the diagnoses deployed by these two traditions are different in many ways, their objectives are the same: establish a strong government able to foment and assist the market functions, reform institutions and put in motion policies that improve macroeconomic stability. Their dissonant data-reading is responsible both for the diverging diagnoses and for the converging objective.

The difference in the way these schools of thought read data lies, above all, on the consideration that post-Keynesianism attributes this need for intervention to fundamental uncertainty, while developmental macroeconomics assigns it mainly to the restrictions imposed to medium industrialized countries by international trade. Therefore, post-Keynesians identify the economy's flaws on the demand side, while for developmental macroeconomists, despite their regard of aggregate demand as paramount, the strangling takes place essentially in the supply side. This is a crucial point of disagreement and one which we believe might foster some strong oppositionist views to our argument.

The fiscal policy employed by these two approaches is essentially the same. Here we find, perhaps, the most direct influence of post-Keynesians over developmental macroeconomics. The fiscal policy recommendation is made up by two budgets, one for administrative spending (that must be balanced) and another concerning the capital spending (that has to respect the budget constraint imposed by the surpluses of the former to finance public investment). The two approaches differ in the relevance they attribute to this mechanism. Corroborating the idea that this device may fill in for the gap left by aggregate demand, post-Keynesians place it as the crucial economic policy. Developmental macroeconomists, on the other hand, despite designating a considerable importance to it, do not regard fiscal policy as more or less important than other policies.

The convergence of the monetary policy is also noticeable, but the prescriptions of the developmental macroeconomists, although influenced by post-Keynesianism, go beyond the proposals of the post-Keynesians. Stability, added to the endorsement urgency, is again in the center for both doctrines, but in different forms. PostKeynesianism preaches that the interest rate must be, respecting the restriction 
imposed by the necessity to assure financial stability, as low as possible, and that this must be indicated to the agents in order to encourage them to invest. Developmental macroeconomics, on the other hand, prays for an expansion of the attributions of the Central Bank, adding the management of the exchange rate to its arsenal (also composed by the consensual interest rate instrument). This would put the equilibrium of the balance of payments at the mercy of the Central Bank. These two devices ought to be intertwined in order to persuade agents to trail the path that policy makers judge as the best one for economic activity. Even though the means are distinct, the monetary mechanisms defended by developmental macroeconomics are very much adherent to the post-Keynesian signalization end.

Moreover, the concern regarding the inflation rise that may be triggered by the interest rate administration is treated differently by the two theories. Stability of prices is central to developmental macroeconomists' monetary policy and the interest rate plays an essential role in this quest. Post-Keynesians, on the other hand, although acquiescing that a low interest rate might have a negative effect upon price stability, reaffirm that it should be held in a level capable of providing financial stability. Therefore, other tools - which are not clearly specified - would be necessary to help in an eventual escalation of the prices' containment.

Regarding the exchange rate, embedded in the monetary system, the focus is the same for both traditions. The exchange rate should be kept in a level that eases a surplus in foreign trade. For post-Keynesians this is a relatively subsidiary practice, in the sense that it is not a highly stressed matter in their framework. For developmental macroeconomists, however, this is the fundamental instrument. The exchange rate policy would thus be the main responsible for the attainment of a higher development level. In the realm of the proposed practices, the convergence of their thoughts is clear and both schools depart from the same idea: the existence of an administered exchange rate that allows for the prosperity of internal industry and a consequent surplus in the balance of payments.

Also embedded in the monetary system is the price policy. Both schools acknowledge that inflation must be kept at a healthy baseline, but the approaches through which they tackle the problem are consistently different.

Post-Keynesians assert that the generation of disproportionate inflation relies on the prices of raw materials and on wages, suggesting the administration of both. Developmental macroeconomists, on the other hand - keeping in mind the interest rate's importance in the management of inflation - suggest, as, for example, Oreiro and Paula (2012, p. 13-14), the reformulation of the inflation-targeting regime. The flagship of this reform, they argue, should be the allowance of a higher freedom degree to the monetary authority in its contingence methods and preoccupations.

Industrial policy, at last, is in a secondary plan for both traditions. In general lines, these traditions hold that there must exist an incentive structure to the overall industrial development of the economy, based on the improvement in the competitive edge of national firms. Among these, the ones that generate a high aggregate value have a special place. 
Table 1: A synthetic comparison between the two approaches

\begin{tabular}{|c|c|c|c|}
\hline & Post-Keynesianism & Developmental Macroeconomics \\
\hline \multicolumn{2}{|c|}{ Objectives } & \multicolumn{2}{|c|}{$\begin{array}{c}\text { Establish a strong government able to foment and assist } \\
\text { the market functions, reform institutions and put in motion } \\
\text { policies that improve macroeconomic stability. }\end{array}$} \\
\hline \multicolumn{2}{|c|}{$\begin{array}{l}\text { Diagnoses and } \\
\text { justification for } \\
\text { State intervention }\end{array}$} & $\begin{array}{l}\text { The uncertain environment } \\
\text { of a monetary economy } \\
\text { of production holds back } \\
\text { the components of aggregate } \\
\text { demand. }\end{array}$ & $\begin{array}{l}\text { International trade } \\
\text { imposes restrictions to the } \\
\text { industrialization of medium } \\
\text { and underdeveloped } \\
\text { countries. }\end{array}$ \\
\hline \multirow{5}{*}{$\begin{array}{c}\text { Policy } \\
\text { prescriptions }\end{array}$} & Fiscal & \multicolumn{2}{|c|}{$\begin{array}{c}\text { Segregation of two budgets: a balanced current } \\
\text { one and a discretionary capital one, operating anti-cyclically; } \\
\text { Post-Keynesians regard it as the main policy instrument; }\end{array}$} \\
\hline & Monetary & $\begin{array}{l}\text { Interest rate must be held at } \\
\text { the lowest level compatible } \\
\text { with financial stability and } \\
\text { the monetary authority must } \\
\text { signal to agents that this level } \\
\text { is propicious to invest; }\end{array}$ & $\begin{array}{l}\text { Central Bank must integrate } \\
\text { interest and exchange rate policies } \\
\text { to guarantee the stability of the } \\
\text { Balance of Payments; agents } \\
\text { should be persuaded to follow the } \\
\text { path understood as the best one } \\
\text { for economic activity; }\end{array}$ \\
\hline & $\begin{array}{c}\text { Exchange } \\
\text { rate }\end{array}$ & \multicolumn{2}{|c|}{$\begin{array}{l}\text { Exchange rate must be held in an administered level that allows } \\
\text { for the prosperity of internal industry and a consequent surplus } \\
\text { in the balance of payments (through a surplus in foreign trade); } \\
\text { Developmental macroeconomists regard it as responsible } \\
\text { for the attainment of a higher development level; }\end{array}$} \\
\hline & Prices & $\begin{array}{l}\text { Raw material prices and } \\
\text { wages, the sources of } \\
\text { disproportionate inflation, } \\
\text { should have their prices } \\
\text { administered; }\end{array}$ & $\begin{array}{c}\text { The inflation-targeting regime must } \\
\text { be reformulated, eliminating the } \\
\text { main supply disturbance factors } \\
\text { and allowing for a higher freedom } \\
\text { degree to the monetary authority } \\
\text { in its contingence methods and } \\
\text { preoccupations; }\end{array}$ \\
\hline & Industrial & \multicolumn{2}{|c|}{$\begin{array}{l}\text { There must be an incentive structure that propels } \\
\text { national firms to compete internationally, enhancing the } \\
\text { industrial development level of the economy, especially } \\
\text { with regard to high-aggregate value industries. }\end{array}$} \\
\hline
\end{tabular}

Source: Elaborated by the author.

Therefore, we believe the relation between developmental macroeconomics and post-Keynesianism, for all the arguments presented, is indeed deep and nearly immeasurable. Furthermore, we believe it is safe to say that new developmentalism would not have been conceived as we know it if there had not been a massive postKeynesian repercussion over the developmental macroeconomics doctrine. 


\section{CONCLUDING REMARKS}

Post-Keynesianism and developmental macroeconomics, as shown, are contiguous in so many points that one can easily get lost in the differentiation between them. The resemblance between these two approaches is such that their exponents are continually interacting with each other - as the verification of the original subscribers of the Ten Theses on New Developmentalism ${ }^{13}$ might indicate. This is a difficulty, as well as a helpful explicit link, that certainly had to be dealt with during the elaboration of this paper.

Nonetheless, we believe this elaboration achieved its goal, that is, of advancing in the comprehension of the influence exercised by post-Keynesianism over developmental macroeconomics. More specifically, we analyzed the relations, differences and similarities of these two heterodox traditions. The conclusion we can take from our analysis is that post-Keynesianism had a crucial influence on the formation of developmental macroeconomics and, consequently, on the new developmentalist strategy. Now that developmental macroeconomics has a more-defined (but still unconsolidated) theoretical body, we might claim, in fact, that these schools exercise a reciprocal impact on each other. An example of this recent "reverse influence" is Chick's (2016, p. 100) consideration of Bresser-Pereira and Lima's (1996) argument in criticizing the microfoundations of macromodels. Bresser-Pereira, as stated in the third section, is the main figure in the developmental macroeconomics tradition.

Among the three elementary points brought to evidence, i.e., the diagnoses, the objectives and the policy recommendations developed by each tradition, the similarities are undeniable. Their diagnoses are opposed, in the sense that while one ascribes the flaws of the economic system mainly to the aggregate demand insufficiency caused by fundamental uncertainty, the other blames the supply side for the malfunctioning of the superstructure. This is not the same as saying that developmental macroeconomics disregards the role played by aggregate demand. In reality, it also assigns a fundamental role to aggregate demand.

Furthermore, despite the dissimilarity in the way they interpret the capitalist dynamics, the objective assigned to government intervention is the same: conduct the market and guarantee macroeconomic stability.

Finally, the policy prescriptions are, except in some specific means, aimed essentially at the same end. Its core shifts, transiting between the fiscal policy for one and the exchange rate policy for the other, but the proposals gravitate around harmonic propositions. These propositions are: a) a balanced fiscal budget; b) the interest rate as a device of both stabilization and investment encouragement; $c$ ) the administration of the exchange rate (striving for the industry's competitiveness); d) reasonable inflation (with divergent mechanisms of control); and e) solid foundations for the industrial prosperity.

${ }^{13}$ Available on www.tenthesesonnewdevelopmentalism.org. 
Accordingly, post-Keynesian proposals crossed the boundaries of post-Keynesianism and conditioned the establishment of developmental macroeconomics. We hope this essay rendered more precision to the understanding of the specific features of this movement.

\section{REFERENCES}

ARESTIS, P.; RESENDE, M. F. (2015) Fiscal policy and the substitution between national and foreign savings. Journal of Post Keynesian Economics, 37(3): 436-458

ARESTIS, P.; SAWYER, M. (1998) Keynesian economic policies for the new millennium. The Economic Journal, 108(1): 181-195

BIELSCHOWSKY, R. (2000) Cinquenta anos de pensamento da Cepal - uma resenha. In: BIELSCHOWSKY, R. Cinquenta anos de pensamento da Cepal: volume 1. Rio de Janeiro; São Paulo: Editora Record

BRESSER-PEREIRA, L. C. (2005) Macroeconomia pós-Plano Real: as relações básicas. In: SICSÚ, J.; PAULA, L. F.; MICHEL, R. Novo-desenvolvimentismo: um projeto nacional de crescimento com equidade social. Barueri: Manole

BRESSER-PEREIRA, L. C.. (2006) The new developmentalism and conventional orthodoxy. Économie Appliquée, 59(3): 95-126

BRESSER-PEREIRA, L. C.. (2007) Estado y mercado en el nuevo desarrollismo. Nueva Sociedad, 210(1): 110-125

BRESSER-PEREIRA, L. C.. (2008) The Dutch disease and its neutralization: a Ricardian approach. Revista de Economia Política, 28(1): 47-71

BRESSER-PEREIRA, L. C.. (2010) Globalization and Competition, New York: Cambridge University Press.

BRESSER-PEREIRA, L. C.. (2011a) An account of new developmentalism and its structuralist macroeconomics. Revista de Economia Politica, 31(3): 493-502

BRESSER-PEREIRA, L. C.. (2011b) Uma escola de pensamento keynesiano-estruturalista no Brasil? Revista de Economia Política, 31(2): 305-314

BRESSER-PEREIRA, L. C.. (2012) Structuralist macroeconomics and the new developmentalism. Revista de Economia Política, 32(3): 347-366

BRESSER-PEREIRA, L. C.. (2014) The access to demand. Keynesian Brazilian Review, 1(1): 35-43.

BRESSER-PEREIRA, L. C.; LIMA, G. T. (1996) The irreducibility of macro to microeconomics: a methodological approach. Revista de Economia Política, 16(2): 15-39

CARNEIRO, R. M. (2012) Velhos e novos desenvolvimentismos. Economia \& Sociedade, 21(Supplement): $749-778$

CARVALHO, F. J. C. (1999) Políticas econômicas para economias monetárias. In: LIMA, G. T.; SICSÚ, J.; LIMA, G. T. Macroeconomia moderna: Keynes e a economia contemporânea. Rio de Janeiro: Editora Campus

CHICK, V. (2016) On microfoundations and Keynes' economics. Review of Political Economy, 28(1): 99-112

DAVIDSON, P. (2002) Financial markets, money and the real world. Cheltenham: Edward Elgar

JESPERSEN, J. (2009) Macroeconomic methodology: a post-Keynesian perspective. Cheltenham: Edward Elgar

KEYNES, J. M. (1936 [1964]) The General Theory of employment, interest and money. San Diego, New York, London: Harcourt, Inc.

LANDRETH, H.; COLANDER, D. (2001) History of economic thought. Boston, Toronto: Houghton Mifflin Company

LAVOIE, M. (2009) Introduction to post-Keynesian economics. New York, Palgrave Macmillan

MINSKY, H. (1986) Stabilizing an unstable economy. New Haven: Yale University Press 
MISSIO, F.; JAYME JR, F.; OREIRO, J. L. (2015) The structuralist tradition in economics: methodological and macroeconomics aspects. Revista de Economia Política, 35(2): 247-266

MOLLO, M. L. R.; AMADO, A. (2015) O debate desenvolvimentista no Brasil: tomando partido. Economia \& Sociedade, 24(1): 1-28

MOLLO, M. L. R.; FONSECA, P. C. D. (2013) Desenvolvimentismo e novo-desenvolvimentismo: raízes teóricas e precisões conceituais. Revista de Economia Política, 33(2): 222-239

OREIRO, J. L. (2011) Economia pós-keynesiana: origem, programa de pesquisa, questões resolvidas e desenvolvimentos futuros. Ensaios FEE, 31(2): 283-312

OREIRO, J. L.; PAULA, L. F. (2012) Novo desenvolvimentismo e a agenda de reformas macroeconômicas para o crescimento sustentado com estabilidade de preços e equidade social. In: BAŚ́LIO, F.; OREIRO, J. L.; PAULA, L. F. Macroeconomia do Desenvolvimento: ensaios sobre restrição externa, financiamento e política macroeconômica. Recife: Editora da UFPE

PREBISCH, R. (1949 [1986]) El desarrollo económico de la America Latina y algunos de sus principales problemas. Desarrollo Económico, 26(103): 479-502

SICSÚ, J.; PAULA, L. F.; MICHEL, R. (2007) Por que novo-desenvolvimentismo? Revista de Economia Política, 27(4): 507-524

SKIDELSKY, R. (1992) John Maynard Keynes: the economist as a savior. New York: Penguin Press

STUDART, R. (1995) O sistema financeiro e p financiamento do crescimento: uma alternativa pós-keynesiana à visão convencional. Revista de Economia Política, 13(1): 101-118

SUNKEL, O.; PAZ, P. (1976) A teoria do desenvolvimento econômico. São Paulo: Rio de Janeiro: Difel 